\title{
THE FLORAL AND SCENT CHARACTERISTICS OF LAVANDIN FROM THE MICROPROPAGATION AND CUTTING PROPAGATION
}

\author{
Nimet KARA ${ }^{1 *}$, Hasan BAYDAR \\ ${ }^{1}$ Isparta University of Applied Sciences, Faculty of Agriculture, Department of Field Crops, Isparta, \\ TURKEY \\ *Corresponding author: nimetkara@isparta.edu.tr
}

Received: 21.04 .2020

\begin{abstract}
The purpose of the study was to compare the floral and scent characteristics of lavandin ((Lavandula $x$ intermedia Emeric ex Loisel.)) from micro propagation and cutting propagation under field condition in Isparta province of Turkey. The experiment was arranged according to a Randomized Complete-Block Design with three replications.

In comparison with the propagation methods, the yield and floral characteristics of the micropropagation were higher than the cutting propagation. The fresh stem flower yield, the dried flower yield, and the examined characteristics of the lavandin were higher in the subsequent years compared to the previous years. While the highest plant height $(90.10 \mathrm{~cm})$, the spike length $(10.16 \mathrm{~cm})$, the leaf length $(56.16 \mathrm{~mm})$, the spike number per plant $\left(479.0\right.$ spike plant $\left.{ }^{-1}\right)$, the cluster number per spike $\left(10.70\right.$ cluster spike $\left.{ }^{-1}\right)$, the fresh stem flower yield (7791.0 kg ha-1), and the dried flower yield $\left(2054.6 \mathrm{~kg} \mathrm{ha}^{-1}\right)$ were obtained from the micropropagation method in the year 2017, the lowest values of these characteristics were determined from the cutting propagation in 2014.

The essential oil contents of the lavandin were not significantly different in both propagation methods. The essential oil contents of fresh stem flower and the dried flower of lavandin were decreased in the subsequent years, and the highest essential oil content (1.27 and $7.36 \%$, respectively) was determined from 2014 , and the lowest essential oil content (1.21 and 6.92\%, respectively) from 2017.

The linalool, linalyl acetate, camphor, $\alpha$-terpineol, and borneol $L$ were close to each other in both propagation methods, while the eucalyptol content of the micropropagation was higher than the cutting propagation.
\end{abstract}

Keywords: Essential oil, lavandin, micropropagation, yield

\section{INTRODUCTION}

Lavender is an important perfume, cosmetic, and medicine plant that is cultivated due to its high essential oil content and quality (Dias et al., 2002). Lavender can be reproduced as both a generative and vegetative. Some lavender species can be rapidly reproduced as only generative or only vegetative, while some species can be reproduced with both methods. For example, with the diploid (2n) lavender $($ L. angustifolia $=$ L. officinalis $=L$. vera) and the tetraploid spike $(4 \mathrm{x})$ lavender ( $L$. spica) cultivars can be reproduced as both generative and vegetative, but $L$. hybrida is not a seed production plant due to infertility. Therefore, the L. hybrida were propagated as a clonal (Segura and Calvo, 1991; Andrade et al., 1999).

The cutting propagation is the most commonly used method in the seedling production of the tree form plants. However, there are disadvantages such as polyploidy, long breeding cycles, and lengthy field trial procedures of the cutting method (Canli and Tian, 2008; Kassaye and
Bekele, 2015). In recent years, significant progress has been made in the field of in vitro techniques and especially in produce via the micropropagation of medicinal and aromatic plants. Each new plant is genetically identical to the original plant in production via the micropropagation method (Chawla, 2009). Micropropagation is a rapid vegetative multiplication with an in vitro technique by using explants such as meristem, shoot tip and embryos (Hutchinson and Zimmerhan, 1987; Ozturk and Yildirim, 2011). There are many advantages such as rapid and large number multiplication of the plants within a short period, the production of independent seasons, virus free plants and the reproduction of plants that are not produced by using classical methods (Bajaj et al., 1988; Ozturk and Yildirim, 2010). In addition, the micropropagation techniques can be an alternative method to the classic vegetative propagation in some plants that are sensitive to environmental conditions (Pierik, 1987). Previous researchers have mentioned that some species can be economically propagated via the micropropagation under in vitro conditions when the rootstock is insufficient 
(Quazi, 1980; Andrade et al., 1999; Nogueira and Romano, 2002; Echeverrigaray et al., 2005). Sudria et al. (1999) reported that the $L$. dentata was successfully propagated via in vitro microporopagation in $0.1 \mathrm{mg} \mathrm{L}^{-1}$ BA and IBA nutrition medium. Another study showed that the Lavandula angustifolia var. Munstead propagated via in vitro micropropagation were successfully planted in the field (Wang et al., 2007).

L. $x$ intermedia var. Super does not produce a seed due to self-sterility. Therefore, it is propagated by cuttings. However, the rooting capability of some lavandin species in cutting propagation is low. In addition, there is a need for a large rootstock garden and a lot of plants to propagate large number of seedlings in the cutting propagation method (Segura and Calvo, 1991). With species produced with seeds, there can be a germination problem, variation in morphology characteristics, essential oil content, and composition because of the crosspollination (Nogueira and Romano, 2002; Zuzarte et al., 2010). Large numerous free-disease, somatic embryos, and seconder metabolites can be quickly produced under controlled conditions via the in vitro method (Zuzarte et al., 2010). Although there were studies conducted with different lavender varieties, explant sources, and nutrient media via micropropagation, there is not sufficient research about the comparisons with the yield and quality characteristics of the plants produced with cutting and in vitro of the lavandin in the field conditions. Therefore, the aim of the research was to compare fresh stem flower and dried flower yields, some plant characteristics, essential oil content and chemical composition of the Super cultivar propagated via cutting (in vivo conditions) and in vitro micropropagation methods.

\section{MATERIALS AND METHODS}

\section{In vitro micropropagation}

For the micropropagation, the shoot tips of the L.x intermedia var. Super species were used as an explant source for three years in 2010. For the shoot propagation and rooting growing, the Murashige and Skoog (1962) medium including $30 \mathrm{~g} \mathrm{~L}^{-1}$ sucrose and $8 \mathrm{~g} \mathrm{~L}^{-1}$ agar under $5.8 \mathrm{pH}$ was used as the basic growth medium. In the shoot proliferation stage, a MS nutrient medium containing 0.49 $\mu \mathrm{M}$ benzylaminopurine $(\mathrm{BA})+0.50 \mu \mathrm{M}$ indole-3-butric acid (IBA) was used, while $0.46 \mu \mathrm{M}$ naphthalenacetic acid (NAA) in the rooting stage were used (Echieverrigaray et al., 2005). The explants were cultured in the growth room in which the temperature was $25^{\circ} \mathrm{C} \pm 2{ }^{\circ} \mathrm{C}$, the light was 16 hours, the darkness was 8 hours, and the light intensity was 3000 Lux (Calvo and Segura, 1989). The cultured ones were put into the sub-culture and then the shoots obtained were transferred into the rooting medium. The rooted shoots were planted into plastic vials including sterile perlite + peat $(1: 1)$ in a $6.5 \times 8.0 \mathrm{~cm}$ diameter in an air conditions. The plantlets in the viols were sprinkle irrigated with a diluted 1/8 free-vitamin MS nutrient medium every day. The lavandin seedlings were kept in an air conditioned room for approximately 3 months. Then, the seedlings were transferred into the pots from the viols for adaptation in greenhouses conditions. The seedlings were continuously monitored under controlled greenhouse conditions and were irrigated with tap water. For the strengthening of the roots of the seedlings, they were kept in pots outside the greenhouse for one year.

\section{Cutting rooting}

For cutting propagation of L.x intermedia var. Super, $10-15 \mathrm{~cm}$ length plant parts were taken from one-year shoots in 2010 year. For the rooting, 4000 ppm indole-3butric acid (IBA) concentration was applied. The lavandin cuttings were kept for 5 seconds in an IBA solution, and then the cutting was planted into the rooting safes including perlite: peat (1:1) in greenhouses conditions. The cuttings were fogging irrigated for two months. After the two months, the well-rooted cuttings were selected and used as seedlings in the experiment.

\section{Planting of seedling}

The lavandin seedlings obtained via the microprpagation and cutting were planted in March in 2011 year as three replications in a Randomized Complete Block Design in the experiment field at the Suleyman Demirel University, Isparta, in Turkey. The distance between the rows was $1 \mathrm{~m}$, and each plot area was $5 \mathrm{~m}$ in length, had 5 rows, and 50 plants. After planting, the seedlings were immediately irrigated, and for the first year were watered three times in order to prevent the seedlings from dying. They were not watered in the following years.

Nitrogen and phosphorus fertilizers were applied each year at a rate of $80 \mathrm{~kg} \mathrm{ha}^{-1}$ and $40 \mathrm{~kg} \mathrm{ha}^{-1}$ in the form of ammonium sulfate and triple super phosphate, respectively. Rotary hoeing was used for weed control. All the necessary agricultural practices were applied identically to the plots. Any observations from the experiment during the first 3 years were not conducted; however, the growing shoots were harvested. The yield and plant characteristic observations in both the propagation methods were conducted in 2014, 2015, 2016 and 2017 years.

\section{Climatic data of the experimental area}

Some climatic data of the experiment area is shown in Table 1. The Isparta Province is located at a $37^{\circ} 45^{\prime} \mathrm{N}$ latitude, $30^{\circ} 33^{\prime} \mathrm{E}$ longitude, and $1050 \mathrm{~m}$ altitude. The long-term annual mean temperature and total annual precipitation in the area are $12.2{ }^{\circ} \mathrm{C}$ and $493.4 \mathrm{~mm}$, respectively. With these climate characteristics, Isparta has features of the semi-arid climatic characteristics found in the Southwestern Anatolia region. The average temperatures in 2014, 2015, 2016, and 2017 were 13.04, $12.91,13.08$, and $11.46{ }^{\circ} \mathrm{C}$, and in these years, the total precipitation was $630.8,582.6,549.2$ and $563.4 \mathrm{~mm}$ respectively (Table 1 ). The average temperatures for the experiment years were similar, and the total precipitation was higher when compared to long-term meteorological data. 


\section{Soil characteristics}

The soil at a depth of $90 \mathrm{~cm}$ was low in organic matter $(1.35 \%)$, in alkaline ( $\mathrm{pH} 8.3)$ and limey $\left(23.45 \% \mathrm{CaCO}_{3}\right)$, low salt (EC: $0.16 \mathrm{ds} / \mathrm{m}$ ) and sandy-loamy.

\section{Yield and yield components}

When the plants reached the full blooming stage, two rows in the center of each plot were harvested manually in July in the experimental years. The plants' characteristics such as plant height, spike length, leaf length, spike number per plant, and cluster number per spike were measured. The fresh stem flower were weighed and dried in the shade at room temperature for a two-week period. The fresh stem flower and dried flower yield were calculated by converting from the parcel yield to hectare (Kara and Baydar, 2013).

\section{Essential oil distillation}

A $200 \mathrm{~g}$ fresh stem flower in $1.5 \mathrm{~L}$ water and $50 \mathrm{~g}$ dried stemless flower samples in $1 \mathrm{~L}$ water from each treatment were extracted by hydro-distillation for 3 hours using the Clevenger apparatus according to the standard procedure described in European Pharmacopoeia (Stainier, 1975) for determining oil content (v/w \%).

Table 1. Some climatic data of the experimental field*

\begin{tabular}{|c|c|c|c|c|c|c|c|c|c|c|c|c|c|c|}
\hline \multirow{2}{*}{$\begin{array}{l}\text { Climatic } \\
\text { factors }\end{array}$} & \multirow{2}{*}{ Years } & \multicolumn{12}{|c|}{ Months } & \multirow{2}{*}{$\begin{array}{l}\text { Total or } \\
\text { Average }\end{array}$} \\
\hline & & Jan. & Feb. & March & April & May & June & July & Aug. & Sept. & Oct. & Nov. & Dec. & \\
\hline \multirow{5}{*}{$\begin{array}{c}\text { Average } \\
\text { temperature } \\
\left({ }^{\circ} \mathbf{C}\right)\end{array}$} & 2014 & 3.7 & 5.2 & 7.3 & 11.7 & 15.1 & 20.0 & 24.5 & 24.9 & 18.4 & 12.9 & 6.8 & 6.0 & 13.04 \\
\hline & 2015 & 1.9 & 3.3 & 6.7 & 9.0 & 18.3 & 20.4 & 24.2 & 23.8 & 21.8 & 14.5 & 8.7 & 2.4 & 12.91 \\
\hline & 2016 & 1.3 & 7.3 & 7.6 & 14.0 & 14.6 & 21.6 & 25.0 & 24.4 & 18.9 & 14.8 & 7.2 & 0.3 & 13.08 \\
\hline & 2017 & -0.8 & 3.0 & 7.3 & 10.6 & 14.9 & 20.1 & 25.1 & 24.0 & 17.8 & 13.2 & 0.3 & 2.1 & 11.46 \\
\hline & Long years & 1.7 & 2.6 & 5.9 & 10.5 & 15.5 & 20.1 & 23.4 & 25.8 & 18.3 & 12.8 & 6.9 & 3.0 & 12.20 \\
\hline \multirow{5}{*}{ Precipitation (mm) } & 2014 & 61.3 & 23.4 & 78.6 & 44.8 & 57.0 & 42.8 & 0.8 & 10.2 & 9.2 & 57.1 & 37.0 & 108.6 & 630.8 \\
\hline & 2015 & 125.9 & 57.7 & 111.6 & 26.1 & 67.5 & 92.2 & 3.0 & 43.4 & 8.2 & 23.1 & 17.5 & 6.4 & 582.6 \\
\hline & 2016 & 101.6 & 33.3 & 59.9 & 47.8 & 87.6 & 32.4 & 25.7 & 45.4 & 31.6 & 21.6 & 48.8 & 33.5 & 549.2 \\
\hline & 2017 & 87.8 & 3.6 & 74.4 & 25.6 & 149.5 & 30.9 & 13.1 & 20.4 & 28.5 & 1.6 & 45.9 & 82.1 & 563.4 \\
\hline & Long years & 64.2 & 54.9 & 52.8 & 58.8 & 46.0 & 27.8 & 12.8 & 0.3 & 15.4 & 38.0 & 51.5 & 70.9 & 493.4 \\
\hline
\end{tabular}

\section{GC-MS analysis}

The GC-MS (Gas Chromatography-Mass Spectrometry) analysis of the essential oil samples was performed on QP5050 GC-MS equipped with a Quadrapole detector. The Lavandin essential oil was stored at $4{ }^{0} \mathrm{C}$ until the GC-MS analyses. $1 \mu \mathrm{L}$ of essential oil diluted with $n$-hexane was injected into the GC-MS system. The GC/MS analysis was employed under the following conditions: the capillary column, CP-Wax 52 $\mathrm{CB}(50 \mathrm{~m} \times 0.32 \mathrm{~mm}$; film thickness $=0.25 \mu \mathrm{m})$; the oven temperature program $\left(60{ }^{0} \mathrm{C}\right.$ increased to $220{ }^{\circ} \mathrm{C}$ at a rate of $2{ }^{\circ} \mathrm{C} / \mathrm{min}$ and was then kept at $220{ }^{\circ} \mathrm{C}$ for $10 \mathrm{~min}$ ); total run time $60 \mathrm{~min}$; injector temperature, $240{ }^{\circ} \mathrm{C}$; detector temperature, $250{ }^{\circ} \mathrm{C}$; carrier gas, helium at a flow rate of $20 \mathrm{~mL} / \mathrm{min}$. The identification of the constituents was carried out with the help of the retention times of standard substances by the composition of the mass spectra with the data given in the NIST library (Stein, 1990).

\section{Statistical analysis}

All the data were analyzed according to the analysis of variance (ANOVA) using SAS Statistical Package Program; the significant differences between the means were separated using the DUNCAN test (Steel and Torrie, 1980).

\section{RESULTS AND DISCUSSION}

\section{Fresh stem flower/dried flower yield and plant characteristics}

The effects of the propagation methods on the plant height, the ear length, the leaf length, the ear number per plant, the cluster number per plant, the fresh stem flower yield, and the dried flower yield were statistically significant for the years and propagation methods (except for the ear length and the leaf length). No significant differences in the subsequent years in all the examined characteristics were found (Table 2).

When the propagation methods were compared, the values from the micropropagation were higher than the cutting propagation in all the examined characteristics (Table 2). The reason for these differences might have been due to better rooting because of the longer time being kept in the pots for adaptation to the atmospheric conditions of the seedling from micropropagation, and because the seedlings with more and longer roots could better benefit from the water and nutrient matter in the soil.

The flower yield and the examined characteristics were higher in the subsequent years compared to the previous years. The highest plant height $(90.10 \mathrm{~cm})$, spike length $(10.16 \mathrm{~cm})$, leaf length $(56.16 \mathrm{~mm})$, spike number per plant $\left(479.0\right.$ spike plant $\left.^{-1}\right)$, cluster number per spike $\left(10.70\right.$ cluster spike $\left.{ }^{-1}\right)$, fresh stem flower yield $(7791.0 \mathrm{~kg}$ 
$\mathrm{ha}^{-1}$ ) and dried flower yield (2054.6 $\left.\mathrm{kg} \mathrm{ha}^{-1}\right)$ were obtained from the micropropagation method in 2017, and the lowest values of these characteristics were determined from the cutting propagation in 2014 (Table 2). The differences between the years might be due to the plants continual growth. In addition, rainfall was higher in May, which is the fastest growing period (the shoot period) in the subsequent years according to the previous years. The plants characteristics such as plant height, stem number, and spike length can be higher than the subsequent year in perennial plants and it was also the reason for the higher yield in following years (Kara and Baydar, 2013; Sonmez et al., 2018). Dias et al. (2002) reported that $80 \%$ of the micropropagated plantlets developed into mature plants in field conditions and showed a high degree of homogeneity with the parent plants. Arabaci and Bayram (2005) found that the dried flower yield of the lavender varied between 700.0 and $5780.0 \mathrm{~kg} \mathrm{ha}^{-1}$. Kara and Baydar (2013) determined that the fresh stem flower yield and dried flower yield of L. $x$ intermedia var. Super were $5878.0 \mathrm{~kg}$ $\mathrm{ha}^{-1}$ and $3260.0 \mathrm{~kg} \mathrm{ha}^{-1}$, respectively, while Baydar and Erbas (2007) determined the mean fresh stem flower and dried flower yield of the variety Super as $2500.0 \mathrm{~kg} \mathrm{ha}^{-1}$ and $500.0 \mathrm{~kg} \mathrm{ha}^{-1}$, respectively, in the Isparta ecological conditions. Sonmez et al. (2018) stated that the fresh herb and flower yield were $69.05 \mathrm{~g} \mathrm{plant}^{-1}$ and $29.2 \mathrm{~g} \mathrm{plant}^{-1}$, respectively. Dias et al. (2002) reported that plantlets from in vitro were successfully adapted to ex-vitro conditions, exhibiting a normal development. Zuzarte et al. (2010) stated that the climatic characteristics, cultivation methods, and propagation techniques affected the growth of the plants and the biodiversity in the field.

\section{Essential oil content}

The essential oil content of the lavandin for the mean of years in different propagation methods was statistically significant. However, the differences in subsequent years and between the propagation methods for this characteristic were not significant (Table 2). The essential oil content of the lavandin was close to each other in both the propagation methods (Table 2). Similar findings were reported by Chambon et al. (1992) with the essential oil content from the micropropagation of the lavenders and lavandins being similar to the parent plants, and by Nogueira and Romano (2002) the essential oils from the micropropagated plants of $L$. viridis were the same as those field-grown plants, and by Zuzarte et al. (2010) the essential oil content of $L$. pedunculata micropropagated plantlets were identical to those produced by the fieldgrowing plants.
The fresh stem flower and dried flower essential oil content of the lavandin decreased in the subsequent years, and the highest essential oil content $(1.27 \%$ and $7.36 \%$, respectively) was determined from 2014, with the lowest essential oil content (1.21\% and $6.92 \%$, respectively) from 2017 (Table 2). This result may be related to the light intensity, because the plants may have received better light in the early years of their development due to them being shorter. Light is essential to the growth and development of plants as it is directly related to the photosynthesis and the biological, biochemical, and morphological processes (Paez et al., 2000). Ganjewala et al. (2008) found that essential oil accumulation is mainly dependent on the developmental stages of the concerned organ/plants parts. Lakusic et al. (2013) reported that the essential oil depends primarily on young and old leaves. The essential oil content of Achillea collina cultivated under low light density decreased (Giorgi et al., 2013). Lima et al. (2017) stated that the essential oil content changed in different light conditions, and the essential oil content of the Piper hispidinervum increased under high light density. In addition, factors such as seasons, genetic, biotic and abiotic, and geographical factors may influence the essential oil content (Gupta and Ganjewala, 2015).

\section{Chemical composition of the essential oil}

The essential oil components and their ratios showed an irregular increase or a decrease depending on whether they were fresh or dried flowers, the propagation methods, and the years. However, the linalool content showed an increased trend from 2014 to 2017 (Table 3 and 4). While the eucalyptol content of the micropropagation was slightly higher than the cutting propagation, the other main components (linalool, linalyl acetate, camphor, $\alpha$ terpineol, and borneol) were close to each other in both propagation methods. Nogueira and Romano (2002) reported that the major components (1.8-cineole, camphor, $\alpha$-pinene, borneol, $\beta$-pinene and $\alpha$-terpineol) of the essential oil of micropropagated plants of $L$. viridis were the same as the clones. Gonçalves et al. (2008) found that the 1,8-cineole and camphor content of the micropropagated plants were similarity to the parent plants, while the amount of $\alpha$-pinene, camphene, $\beta$-pinene, $\beta$-selinene, and selina-3,7(11)-diene were greater when compared to the parent plant. Zuzarte et al. (2010) stated that the 1,8-cineole and camphor were the same in the in vitro propagated plantlets as in the parent plants, while slight differences occurred in the amounts of $\alpha$ pinene and bornyl acetate. 
Table 2. Effects of propagation methods on the yield, some plant characteristics and essential oil content of L.x intermedia var. Super

\begin{tabular}{|c|c|c|c|c|c|c|c|c|c|c|}
\hline \multirow{2}{*}{$\begin{array}{l}\text { Propagation } \\
\text { Methods/Years }\end{array}$} & \multicolumn{5}{|c|}{ Plant height (cm) } & \multicolumn{5}{|c|}{ Spike length $(\mathrm{cm})$} \\
\hline & 2014 & 2015 & 2016 & 2017 & Mean & 2014 & 2015 & 2016 & 2017 & Mean \\
\hline Micropropagation & 69.70 & 75.80 & 82.90 & 90.10 & $79.60 \mathrm{~A}$ & 8.83 & 9.83 & 9.93 & 10.16 & 9.68 \\
\hline $\begin{array}{l}\text { Cutting } \\
\text { propagation }\end{array}$ & 69.40 & 72.20 & 76.70 & 87.40 & $76.40 \mathrm{~B}$ & 8.70 & 9.32 & 9.70 & 9.60 & 9.33 \\
\hline Years & $69.50 \mathrm{C}$ & $74.10 \mathrm{C}$ & $79.80 \mathrm{~B}$ & $88.70 \mathrm{~A}$ & & $8.76 \mathrm{~B}$ & $9.58 \mathrm{AB}$ & $9.81 \mathrm{~A}$ & $\begin{array}{l}9.88 \mathrm{~A} \\
\mathrm{~B}\end{array}$ & \\
\hline \multicolumn{6}{|c|}{ F valueYears:33.39**, F value propagation mean: $8.49 *$} & \multicolumn{5}{|c|}{ F valueYears: $8.4^{*}, \quad F$ value propagation mean: $1.60^{\mathrm{ns}}$} \\
\hline $\mathrm{CV}(\%)$ & 5.96 & 6.55 & 1.84 & 3.53 & & 10.21 & 10.14 & 4.57 & 7.68 & \\
\hline \multirow{2}{*}{$\begin{array}{l}\text { Propagation } \\
\text { Methods/Years }\end{array}$} & \multicolumn{5}{|c|}{ Leaf length (mm) } & \multicolumn{5}{|c|}{ Spike number per plant (spike pant $\left.{ }^{-1}\right)$} \\
\hline & 2014 & 2015 & 2016 & 2017 & Mean & 2014 & 2015 & 2016 & 2017 & Mean \\
\hline Micropropagation & 44.5 & 48.22 & 49.55 & 56.16 & 49.62 & 250.07 & 260.0 & 377.3 & 479.0 & $346.6 \mathrm{~A}$ \\
\hline $\begin{array}{l}\text { Cutting } \\
\text { propagation }\end{array}$ & 45.73 & 47.06 & 49.73 & 54.73 & 49.31 & 238.67 & 255.1 & 361.4 & 460.7 & $323.9 \mathrm{~B}$ \\
\hline Years & $45.14 \mathrm{D}$ & $47.64 \mathrm{C}$ & $49.64 \mathrm{~B}$ & $55.45 \mathrm{~A}$ & & $244.3 \mathrm{C}$ & $257.5 \mathrm{C}$ & $369.3 \mathrm{~B}$ & $469.3 \mathrm{~A}$ & \\
\hline F value Year x P.M & $0.82^{\mathrm{ns}}$ & $3.02^{\mathrm{ns}}$ & $1.09^{\mathrm{ns}}$ & $2.90^{\mathrm{ns}}$ & & $0.74^{\mathrm{ns}}$ & $2.38^{\mathrm{ns}}$ & $1.10^{\mathrm{ns}}$ & $1.59^{\mathrm{ns}}$ & \\
\hline \multicolumn{6}{|c|}{ F valueYears:396.58, F value propagation mean: $1.47^{\mathrm{ns}}$} & \multicolumn{5}{|c|}{ F valueyears: $143.83^{* *}, \mathrm{~F}$ value propagation mean: $6.61 *$} \\
\hline $\mathrm{CV}(\%)$ & 3.54 & 1.70 & 2.44 & 1.82 & & 6.32 & 10.86 & 3.67 & 3.78 & \\
\hline \multirow{2}{*}{$\begin{array}{l}\text { Propagation } \\
\text { Methods/Years }\end{array}$} & \multicolumn{5}{|c|}{ Cluster number per spike (cluster spike $^{-1}$ ) } & \multicolumn{5}{|c|}{ Fresh stem flower yield $\left(\mathrm{kg} \mathrm{ha}^{-1}\right)$} \\
\hline & 2014 & 2015 & 2016 & 2017 & Mean & 2014 & 2015 & 2016 & 2017 & Mean \\
\hline Micropropagation & 8.66 & 9.96 & 10.03 & 10.70 & $9.59 \mathrm{~A}$ & $4819.0 \mathrm{a}$ & 5499.3 & 7264.3 & 7791.0 & $\begin{array}{l}6343.4 \\
\text { A }\end{array}$ \\
\hline $\begin{array}{l}\text { Cutting } \\
\text { propagation }\end{array}$ & 8.33 & 8.56 & 9.13 & 9.76 & $8.95 \mathrm{~B}$ & $4514.1 \mathrm{~b}$ & 5350.1 & 6872.4 & 7632.3 & $6092.2 B$ \\
\hline Years & $8.50 \mathrm{C}$ & $8.76 \mathrm{C}$ & $9.58 \mathrm{~B}$ & $10.23 \mathrm{~A}$ & & $4666.5 \mathrm{D}$ & $\begin{array}{l}5424.8 \\
\mathrm{C}\end{array}$ & $\begin{array}{l}7068.3 \\
\text { B }\end{array}$ & $\begin{array}{l}7711.7 \\
\text { A }\end{array}$ & \\
\hline$F$ value Year $x$ P.M & $1.56^{\mathrm{ns}}$ & $3.00^{\mathrm{ns}}$ & $9.57^{\mathrm{ns}}$ & $6.17^{\mathrm{ns}}$ & & $\begin{array}{l}1476.5^{*} \\
*\end{array}$ & $1.25^{\mathrm{ns}}$ & $8.75^{\mathrm{ns}}$ & $1.99^{\mathrm{ns}}$ & \\
\hline \multicolumn{6}{|c|}{ F value Years: $29.76^{* *}, \mathrm{~F}$ value propagation mean: $19.63^{* *}$} & \multicolumn{5}{|c|}{ F valueYears: $271.54 * *, F$ value propagation mean: $8.58 *$} \\
\hline $\mathrm{CV}(\%)$ & 3.84 & 3.22 & 3.38 & 4.49 & & 2.20 & 6.67 & 2.29 & 3.78 & \\
\hline \multirow{2}{*}{$\begin{array}{l}\text { Propagation } \\
\text { Methods/Years }\end{array}$} & \multicolumn{5}{|c|}{ Dried flower yield $\left(\mathrm{kg} \mathrm{ha}^{-1}\right)$} & \multicolumn{5}{|c|}{ Fresh stem flower essential oil content (\%) } \\
\hline & 2014 & 2015 & 2016 & 2017 & Mean & 2014 & 2015 & 2016 & 2017 & Mean \\
\hline Micropropagation & 1122.0 & 1435.3 & 1895.0 & 2054.6 & $\begin{array}{l}1621.7 \\
\text { A }\end{array}$ & 1.28 & 1.26 & 1.25 & 1.23 & 1.25 \\
\hline $\begin{array}{l}\text { Cutting } \\
\text { propagation }\end{array}$ & 1053.6 & 1319.6 & 1724.6 & 1888.3 & 1499.1B & 1.26 & 1.23 & 1.20 & 1.20 & 1.22 \\
\hline Years & $\begin{array}{l}1082.8 \\
\mathrm{D}\end{array}$ & $\begin{array}{l}1377.5 \\
\mathrm{C}\end{array}$ & $\begin{array}{l}1809.8 \\
\text { B }\end{array}$ & $\begin{array}{l}1971.5 \\
\text { A }\end{array}$ & & $1.27 \mathrm{~A}$ & $1.24 \mathrm{~B}$ & $1.23 \mathrm{BC}$ & $1.21 \mathrm{C}$ & \\
\hline \multicolumn{6}{|c|}{ FvalueYears: $101.13^{* *}, \mathrm{~F}$ value propagation mean: $9.26^{*}$} & \multicolumn{5}{|c|}{ FvalueYears: $10.55^{* *}, \mathrm{~F}$ value propagation mean: $1.31^{\mathrm{ns}}$} \\
\hline $\mathrm{CV}(\%)$ & 4.81 & 7.40 & 6.68 & 5.97 & & 2.15 & 1.98 & 1.85 & 2.74 & \\
\hline
\end{tabular}

\begin{tabular}{|c|c|c|c|c|c|}
\hline \multirow{2}{*}{$\begin{array}{l}\text { Propagation } \\
\text { Methods/Years }\end{array}$} & \multicolumn{5}{|c|}{ Dried flower essential oil content (\%) } \\
\hline & 2014 & 2015 & 2016 & 2017 & Mean \\
\hline Micropropagation & 7.45 & 7.63 & 7.31 & 7.13 & 7.25 \\
\hline $\begin{array}{l}\text { Cutting } \\
\text { propagation }\end{array}$ & 7.28 & 7.30 & 6.87 & 6.71 & 7.12 \\
\hline Years & $7.36 \mathrm{~A}$ & $7.46 \mathrm{~A}$ & $7.01 \mathrm{~B}$ & $6.92 \mathrm{~B}$ & \\
\hline F value Year x P.M & $0.89^{\mathrm{ns}}$ & $2.80^{\mathrm{ns}}$ & $2.05^{\mathrm{ns}}$ & $2.60^{\mathrm{ns}}$ & \\
\hline \multicolumn{6}{|c|}{ F valueYears: $16.56 * *, \quad F$ value propagation mean: $3.69^{\text {ns }}$} \\
\hline
\end{tabular}

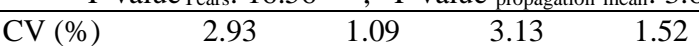

*, **: Significant at $\mathrm{P}<0.05$ and $\mathrm{P}<0.01$ probability levels, respectively.

ns: Non significant, P.M: Propagation methods. 
In the fresh stem flowers, while the linalool, linalyl acetate, camphor, 1,8-cineole, $\alpha$-terpineol, and borneol varied between 45.24-46.38\%, 22.87-23.79\%, 4.22$6.44 \%, 4.98-5.68 \%, 4.24-4.68 \%$ and $4.25-6.31 \%$, respectively, in the micropropagation method, and the rates of these components varied between 45.23-45.86\%, $23.09-23.74 \%, 5.24-6.89 \%, 3.98-4.69 \%, 4.41-5.59 \%$ and $3.63-4.15 \%$ respectively, in the cutting propagation method (Table 3 ). In the dried flower, while the linalool, linalyl acetate, camphor, 1,8-cineole, $\alpha$-terpineol, and borneol varied between 44.51-45.87\%, 23.38-24.06\%, $4.60-6.75 \%, 5.90-6.97 \%, 4.02-4.57 \%$ and $2.46-5.27 \%$, respectively, in the micropropagation method, the rates of these components varied between $44.49-45.24 \%, 23.35-$ $24.43 \%, 4.05-6.89 \%, 4.22-5.92 \%, 4.05-4.50 \%$ and $2.04-$
$4.48 \%$, respectively, in the cutting propagation (Table 4). Monoterpene synthesis can be varied through acetylation, oxidation, or reduction reactions (Boeckelmann, 2008). The same research stated that monoterpene synthesis and accumulation are controlled by the development of the oil glands during the growth season. Previous researchers have mentioned that monoterpene synthesis correlated with the formation of other terpenes. For example, the geraniol, linalool, myrcene, and $\beta$-ocimene were derived from geranyl and the linalyl acetate, while the camphor was produced from the borneol and linalool acetate from the linalool (Boeckelmann, 2008; Degenhardt et al., 2009; Sarker, 2013).

Table 3. Chemical composition of essential oil in the fresh stem flower of $L . x$ intermedia var. Super in different propagation methods

\begin{tabular}{|c|c|c|c|c|c|c|c|c|c|c|c|c|}
\hline \multirow{2}{*}{$\begin{array}{l}\text { Propagation } \\
\text { methods / Years } \\
\text { Chemical } \\
\text { compositions }(\%)\end{array}$} & \multicolumn{6}{|c|}{ Micropropagation } & \multicolumn{6}{|c|}{ Cutting propagation } \\
\hline & RT & 2014 & 2015 & 2016 & 2017 & Mean & RT & 2014 & 2015 & 2016 & 2017 & Mean \\
\hline$\alpha$-Pinene (-)- & 6.68 & 0.25 & 0.26 & 0.21 & 0.19 & 0.23 & 6.70 & 0.17 & 0.18 & 0.22 & 0.28 & 0.21 \\
\hline Camphene & 7.25 & 0.25 & 0.22 & 0.15 & 0.16 & 0.20 & 7.27 & 0.23 & 0.26 & 0.19 & 0.21 & 0.22 \\
\hline$\beta$-Pinene & 8.29 & 0.24 & 0.26 & 0.29 & 0.28 & 0.27 & 8.50 & 0.25 & 0.29 & 0.31 & 0.36 & 0.30 \\
\hline 3-Octanone & 8.54 & 0.43 & 0.46 & 0.51 & 0.55 & 0.49 & 8.57 & 0.58 & 0.60 & 0.57 & 0.70 & 0.61 \\
\hline$\beta$-Myrcene & 8.73 & 0.58 & 0.85 & 1.47 & 1.35 & 1.06 & 8.76 & 0.58 & 0.98 & 1.43 & 1.65 & 1.16 \\
\hline 1-Hexyl acetate & 9.71 & 0.31 & 0.54 & 0.63 & 0.43 & 0.48 & 9.74 & 0.39 & 0.58 & 0.63 & 0.78 & 0.60 \\
\hline Limonene & 10.55 & 0.79 & 0.41 & 0.45 & 0.52 & 0.54 & 10.58 & 0.73 & 0.76 & 0.74 & 0.81 & 0.76 \\
\hline Bornylene & 10.59 & 0.85 & 0.87 & 0.94 & 0.90 & 0.89 & 10.69 & 0.77 & 0.98 & 0.84 & 1.00 & 0.90 \\
\hline $\begin{array}{l}\text { Eucalyptol }(1,8- \\
\text { cineole })\end{array}$ & 10.70 & 530 & & & 1 & 34 & & 4.69 & 308 & 3.96 & 4.62 & 4.31 \\
\hline Cis-Ocimene & 10.91 & 1.08 & 1.10 & 14 & 1.25 & 1.14 & 10.91 & 1.02 & 1.04 & 1.07 & 1.68 & 1.20 \\
\hline$\beta$-Ocime & 11.44 & 1.12 & 1.18 & 1.48 & 1.56 & 1.34 & 11.60 & 1.47 & 1.38 & 1.56 & 1.92 & 1.58 \\
\hline Linalool oxide cis & 12.66 & 0.78 & 0.66 & 0.75 & 0.79 & 0.75 & 12.69 & 0.73 & 0.77 & 0.85 & 0.87 & 0.81 \\
\hline Linalooll & 14.50 & 45.24 & 45.60 & 45.89 & 46.38 & 45.77 & 14.53 & 45.39 & 45.23 & 45.70 & 45.86 & 45.54 \\
\hline $\begin{array}{l}\text { Prop. acid, hexyl } \\
\text { ester }\end{array}$ & 14.69 & 0.26 & 0.31 & 0.28 & 0.29 & 0.29 & 14.69 & 0.26 & 0.32 & 0.29 & 0.24 & 0.28 \\
\hline $\begin{array}{l}1 \text { Octen } 3 \mathrm{YL} \\
\text { acetate }\end{array}$ & 14.78 & 0.25 & 0.23 & 0.24 & 0.21 & 0.23 & 14.82 & 0.35 & 0.31 & 0.29 & 0.32 & 0.32 \\
\hline Camphor & 1 & & & & & & & 3.40 & 2 & 0.89 & 5.24 & 5.88 \\
\hline Borneol & 18.54 & 4.79 & 4.25 & 4.97 & 6.31 & 5.08 & 18.57 & 4.15 & 3.79 & 3.63 & 3.76 & 3.83 \\
\hline 4-Terpineol & 19.06 & 0.50 & 0.60 & 0.47 & 0.55 & 0.53 & 19.25 & 0.56 & 0.49 & 0.61 & 0.54 & 0.55 \\
\hline$\alpha$-terpineol & 20.04 & 4.24 & 4.68 & 4.37 & 4.25 & 4.39 & 20.07 & 4.41 & 4.99 & 5.59 & 4.89 & 4.97 \\
\hline Nerol & 22.04 & 0.68 & 0.61 & 0.62 & 0.69 & 0.65 & 22.03 & 0.45 & 0.56 & 0.64 & 0.76 & 0.60 \\
\hline Linalyl acetate & 23.79 & 23.62 & 22.87 & 23.26 & 23.79 & 23.39 & 23.84 & 23.45 & 23.74 & 23.09 & 23.19 & 23.37 \\
\hline Lavandulyl acetate & 25.95 & 2.30 & 2.45 & 2.25 & 1.93 & 2.23 & 25.98 & 3.14 & 2.66 & 2.16 & 2.60 & 2.64 \\
\hline Neryl acetate & 32.08 & 1.35 & 1.36 & 1.24 & 1.35 & 1.33 & 30.82 & 0.84 & 0.92 & 1.09 & 1.15 & 1.00 \\
\hline $\begin{array}{l}\text { (-)-Caryophyllene } \\
\text { oxide }\end{array}$ & 44.34 & 0.30 & 0.35 & 0.37 & 0.51 & 0.38 & 44.35 & 0.33 & 0.38 & 0.43 & 0.61 & 0.44 \\
\hline cis -Farnesol & 50.60 & 0.20 & 0.28 & 0.45 & 0.30 & 0.31 & 50.61 & 0.43 & 0.47 & 0.56 & 0.81 & 0.57 \\
\hline
\end{tabular}


Table 4. Chemical composition of essential oil in the dried flower of L. x intermedia var. Super in different propagation methods

\begin{tabular}{|c|c|c|c|c|c|c|c|c|c|c|c|c|}
\hline \multirow{2}{*}{$\begin{array}{l}\text { Propagation methods / } \\
\text { Years } \\
\text { Chemical compositions } \\
(\%)\end{array}$} & \multicolumn{6}{|c|}{ Micropropagation } & \multicolumn{6}{|c|}{ Cutting propagation } \\
\hline & RT & 2014 & 2015 & 2016 & 2017 & Mean & RT & 2014 & 2015 & 2016 & 2017 & Mean \\
\hline$\alpha$-Pinene (-)- & 6.70 & 0.22 & 0.19 & 0.20 & 0.23 & 0.21 & 6.70 & 0.27 & 0.16 & 0.17 & 0.15 & 0.19 \\
\hline Camphene & 7.27 & 0.26 & 0.23 & 0.22 & 0.21 & 0.23 & 7.28 & 0.17 & 0.19 & 0.22 & 0.18 & 0.19 \\
\hline 3-Octanone & 8.57 & 0.38 & 0.45 & 0.40 & 0.62 & 0.46 & 8.57 & 0.44 & 0.52 & 0.47 & 0.61 & 0.51 \\
\hline$\beta$-Myrcene & 8.76 & 0.49 & 0.76 & 0.81 & 1.45 & 0.88 & 8.77 & 0.46 & 0.98 & 1.66 & 1.38 & 1.12 \\
\hline 1-Hexyl acetate & 9.74 & 0.30 & 0.39 & 0.41 & 0.75 & 0.46 & 9.75 & 0.31 & 0.47 & 0.50 & 0.80 & 0.52 \\
\hline Limonene & 10.59 & 0.81 & 0.89 & 0.83 & 0.87 & 0.85 & 10.58 & 0.48 & 0.58 & 0.53 & 0.59 & 0.55 \\
\hline Bornylene & 10.61 & 0.48 & 0.63 & 0.58 & 0.81 & 0.63 & 10.59 & 0.66 & 0.63 & 0.71 & 0.77 & 0.69 \\
\hline Eucalyptol (1,8-cineole) & 10.73 & 6.39 & 6.97 & 5.91 & 5.90 & 6.29 & 10.73 & 4.22 & 4.52 & 5.92 & 4.78 & 4.86 \\
\hline$\beta$-Ocimene Y & 11.44 & 0.18 & 0.35 & 0.23 & 0.29 & 0.26 & 11.44 & 0.24 & 0.19 & 0.18 & 0.32 & 0.23 \\
\hline Linalool oxide cis & 13.56 & 0.57 & 0.55 & 0.61 & 1.12 & 0.71 & 12.70 & 1.08 & 1.24 & 1.30 & 1.32 & 1.24 \\
\hline Linalooll & 14.55 & 44.94 & 44.51 & 45.15 & 45.87 & 45.12 & 14.52 & 44.49 & 44.86 & 44.71 & 45.24 & 44.83 \\
\hline 1 Octen 3 YL acetate & 14.82 & 0.26 & 0.33 & 0.24 & 0.28 & 0.28 & 1.82 & 0.33 & 0.51 & 0.77 & 0.92 & 0.63 \\
\hline Camphor & 17.00 & 4.60 & 5.58 & 5.47 & 6.75 & 5.60 & 16.99 & 4.05 & 5.52 & 6.89 & 5.73 & 5.55 \\
\hline Borneol & 18.58 & 5.27 & 4.33 & 3.77 & 2.46 & 3.96 & 18.87 & 4.48 & 3.36 & 2.53 & 2.04 & 3.10 \\
\hline Cryptone & 19.42 & 0.49 & 0.36 & 0.30 & 0.33 & 0.37 & 19.42 & 0.46 & 0.42 & 0.51 & 0.56 & 0.49 \\
\hline$\alpha$-terpineol & 20.07 & 4.02 & 4.26 & 4.57 & 4.35 & 4.30 & 20.07 & 4.50 & 4.26 & 4.05 & 4.08 & 4.22 \\
\hline Nerol & 22.04 & 0.55 & 0.41 & 0.62 & 0.69 & 0.57 & 22.04 & 0.48 & 0.39 & 0.50 & 0.57 & 0.49 \\
\hline Linalyl acetate & 23.84 & 23.38 & 23.78 & 24.06 & 23.43 & 23.66 & 23.84 & 24.34 & 24.43 & 23.62 & 23.35 & 23.94 \\
\hline Lavandulyl acetate & 25.98 & 3.34 & 3.46 & 3.53 & 3.25 & 3.40 & 25.97 & 3.68 & 3.66 & 3.78 & 3.20 & 3.58 \\
\hline Neryl acetate & 32.11 & 1.62 & 1.29 & 1.12 & 0.97 & 1.25 & 30.82 & 0.85 & 1.09 & 1.53 & 1.01 & 1.12 \\
\hline (-)-Caryophyllene oxide & 44.36 & 0.34 & 0.42 & 0.49 & 0.35 & 0.40 & 44.35 & 0.35 & 0.37 & 0.45 & 0.35 & 0.38 \\
\hline cis-Farnesol & 50.62 & 0.66 & 0.65 & 0.61 & 0.75 & 0.67 & 50.61 & 0.35 & 0.48 & 0.47 & 0.51 & 0.45 \\
\hline
\end{tabular}

RT: Retention time.

\section{CONCLUSIONS}

Based on the results of the research we can conclude the following: (i). Lavandin can be successfully propagated via micropropagation. (ii). The floral characteristics of the lavandin produced via the micropropagation were higher than in the cutting propagation. (iii). The essential oil content in both propagation methods was not significantly different. (iv). Linalool, linalyl acetate, camphor, $\alpha$-terpineol, eucalyptol and borneol were identified as major compounds of the lavandin essential oil, and these scent compounds were proportionally close to each other (except for in the eucalyptol) in both propagation methods and years.

\section{LITERATURE CITED}

Andrade, L.B., S. Echeverrigaray, F. Fracaro, G.F. Pauletti and L. Rota. 1999. The effect of growth regulators on shoot propagation and rooting of common lavender (Lavandula vera D.C.). Plant Cell, Tissue and Organ Culture 56 (2): 7983.

Arabaci, O. and E. Bayram. 2005. The effect of nitrogen fertilization and plant density on some agronomic and quality traits of lavender (Lavandula angustifolia Mill.) under ecological conditions of Aydın. Adnan Menderes University Journal of Agriculture Faculty 2(2): 13-19 (in Turkish).

Bajaj, Y.P.S., M. Furmanowa and O. Olszowska. 1988 Biotechnology of the micropropagation of medicinal and aromatic plants. Biotechnology in Agriculture and Forestry 4(2): 60-103.

Baydar, H. and S. Erbas. 2007. Effects of harvest time and drying on essential oil properties in lavandin (Lavandula $x$ intermedia Emeric ex Loisel.). I. International Medicinal and Aromatic Plants Conference on Culinary Herbs, pp. 377-381, 29 April-4 May 2007, Antalya-Turkey.
Boeckelmann, A. 2008. Monoterpene production and regulation in lavenders (Lavandula angustifolia and Lavandula $x$ intermedia). The Master Thesis, University of British Columbia, $98 \mathrm{p}$.

Calvo, M.C. and J. Segura. 1989. Plant regeneration from cultured leaves of Lavandula latifolia Medicus: Influence of growth regulators and illumination conditions. Plant Cell, Tissue and Organ Culture 19(1): 33-42.

Canli, F.A. and L. Tian. 2008. In vitro shoot regeneration from stored mature cotyledons of sweet cherry (Prunus avium L.) cultivars. Scientia Horticulturae 116(1): 34-40.

Chambon, C., A. Poupet, D. Beck, B. Bettachini and J. Touche. 1992. In vitro morphogenetic potential of various lavandin and lavender clones: Preliminary observations on the agronomic value of the vitroplants. Agronomie (Paris) 12(1): 173-181.

Chawla, H.S. 2009. Introduction to Plant Biotechnology, $3^{\text {rd }}$ ed. Science Publishers, Enfield, NH, USA.

Dias, M.C., R. Almeida and A. Romano. 2002. Rapid clonal multiplication of Lavandula viridis through in vitro axillary shoot proliferation. Plant Cell, Tissue and Organ Culture 68(1): 99-102.

Degenhardt, J., T.G. Koellner and J. Gershenzon. 2009. Monoterpene and sesquiterpene synthases and the origin of terpene skeletal diversity in plants. Phytochemistry 70(1516): 1621-37.

Echeverrigaray, E., R. Basso and L.B. Andrade. 2005. Micropropagation of Lavandula dentata from axillary buds of field-grown adult plants. Biologia Plantarum 49(3): 439442.

Ganjewala, D., A. Kumari and K.H. Khan. 2008. Ontogenic and developmental changes in essential oil content and compositions in Cymbopogon flexuosus cultivars. In Prasad BN, Lazer Mathew, eds. Recent Advance in Biotechnology. Excel India Publishers, New Delhi, India, pp. 82-92.

Giorgi, A., S. Panseri, M.S. Mattara, C. Andreis and L.M. Chiesa. 2013. Secondary metabolites and antioxidant 
capacities of Waldheimia glabra (Decne.) Regel from Nepal. Journal Science Food Agriculture 93(5): 1026-1034.

Gonçalves, S., H. Serra, J.M.F. Nogueira, R. Almeida, L. Custodio, L. and A. Romano. 2008. Headspace-SPME of in vitro shoot-cultures and micropropagated plants of Lavandula viridis. Biologia Plantarum 52(1): 133-136.

Gupta, A.K. and D. Ganjewala. 2015. A study on developmental changes in essential oil content and composition in Cymbopogon flexuosus cultivar. Acta Biologica Szegediensis 59(2): 119-125.

Hutchinson, J.F. and R.H. Zimmerhan. 1987. Tissue culture of temperate fruit and nut trees. Horticultural Reviews 9(2): 273-349.

Kara, N. and H. Baydar. 2013. Determination of lavender and lavandin cultivars (Lavandula sp.) containing high quality essential oil in Isparta, Turkey. Turkish Journal of Field Crops 18(1): 58-65.

Kassaye, E. and B.D. Bekele. 2015. In vitro optimization of the protocol for micropropagation of plum (Prunus salicina L. Var. Methley) from nodal explants. Biotechnology International 8(4): 137-148.

Lakusic, B.S., M.S. Ristic, V.N. Slavkovska, D.L. Stojanovic and D.V. Lakusic. 2013. Variations in essential oil yields and compositions of Salvia officinalis (Lamiaceae) at different developmental stages. Botanica Serbica 37(2): 127139.

Lima, V.A., F.V. Pacheco, R.P. Avelar, I.C.A. Alvarenga, J.E.B.P. Pinto, A.A. De Alvarenga. 2017. Growth, photosynthetic pigments and production of essential oil of long-pepper under different light conditions. Annals of the Brazilian Academy of Science 89(2): 1167-1174. https://doi.org/10.1590/0001-3765201720150770

Murashige, T. and F. Skoog. 1962. A revised medium for rapid growth and bioassay with tabocco tissue culture. Physiology Plantarum 15: 473-497.

Nogueira, J.M.F. and A. Romano. 2002. Essential oils from micropropagated plants of Lavandula viridis. Phytochemical Analysis 13(1): 4-7.

Ozturk, G. and Z. Yildirim. 2010. A comparision of field performances of minitubers and microtubers used in seed potato production. Turkish Journal of Field Crops 15(2): 141-147.
Ozturk, G. and Z. Yildirim. 2011. Uniformity of potato minitubers derived from meristem cultures of nuclear seed stocks. Turkish Journal of Field Crops 16(2): 149-152.

Paez, A., G.M. Gebre, M.E. Gonzalez and T.J. Tschaplinski. 2000. Growth, soluble carbohydrates, and aloin concentration of Aloe vera plants exposed to three irradiance levels. Environmental Experimental Botany 44(2): 133-139.

Pierik, R.L.M. 1987. In vitro Culture of Higher Plants. Martinus Nijhoff Publishers, Dordrect 344p.

Quazi, M.H. 1980. In vitro propagation of Lavandula spp. Annals Botany 45: 361-362.

Sarker, L.S. 2013. Cloning of Lavandula essential oil biosynthetic genes. The Master Thesis, The University of British Columbia, 111p.

Segura, J. and M.C. Calvo. 1991. Lavandula spp. (Lavender): In vitro culture, regeneration of plants and formation of essential oils and pigments. Biotechnology in Agriculture and Forestry 15:283-310.

Sonmez, C., A.O.S Soysal, H. Okkaoglu, U. Karik, A.H. Taghiloofar and E. Bayram. 2018. Determination of some yield and quality characteristics among individual plants of lavender (Lavandula angustıfolıa MILL.) populations grown under Mediterranean conditions in Turkey. Pakistan Journal of Botany 50(6): 2285-2290.

Stainier, C. 1975. Role and functions of the European Pharmacopoeia. Ann Ist Super Sanita 11(3-4): 211-219.

Steel, R.G.D. and J.H. Torrie. 1980. Principles and Procedures of Statistics. $2^{\text {nd }}$ edition, McGraw-Hill Book Co. New York.

Stein, S.E. 1990. National Institute of Standards and Technology (NIST) Mass Spectral Database and Software, Version 3.02 USA.

Sudria, C., M.T. Pinol, J. Palazon, R.M. Cusido, R. Vila, C. Morales, M. Bonfill and S. Canigueral. 1999. Influence of plant growth regulators on the growth and essential oil content of cultured Lavandula dentate plantlets. Plant Cell, Tissue and Organ Culture 58(3): 177-184.

Wang, X., L. Jin., M. Li, M. Zhao, H. Zhao, Y. Xu. 2007. Bioreactor culture and plant regeneration from cell clusters of the aromatic plant, Lavandula angustifolia 'Munstead'. Journal of Horticultural Science and Biotechnology 82(5):781-785.

Zuzarte, M., A.M. Dinis, C.C. Ligia, R. Salgueiro and J. Canhoto. 2010. Trichomes, essential oils and in vitro propagation of Lavandula pedunculata (Lamiaceae). Industrial Crops and Products 32(3): 580-587. 